TEME, г. XLII, бр. 4, октобар - децембар 2018, стр. 1297-1317

Оригинални научни рад

DOI: $10.22190 /$ TEME1804297S

Примљено: 29. 11. 2017.

Ревидирана верзија: 3. 2. 2018.

Одобрено за штампу: 12. 6. 2018.

\title{
THE EFFECT OF A PRODUCT'S COUNTRY OF ORIGIN ON THE CUSTOMER LOYALTY CREATION PROCESS
}

\author{
Srđan Šapić”, Milan Kocić, Katarina Radaković \\ University of Kragujevac, Faculty of Economics, Kragujevac, Serbia \\ ssapic@kg.ac.rs
}

\begin{abstract}
Due to the increasing process of globalization, consumers' attitudes and beliefs are formed under the influence of numerous factors, which are not being considered to a large degree when it comes to doing business on a national level, but which may have significant implications on evaluation of international and global aspects of company's operation. One of these factors is the country of origin of products. Although there is a large number of papers in the field of international marketing which investigate issues of the relation of consumers' loyalty and country of origin of products, the originality of this research arises from the fact that, this paper examines the influence of the country of origin of the products on consumers' loyalty, not directly, but observed via specific characteristics of the product, such as quality, design and prestige. Using a regression analysis, it examines the effect of the country of origin of a product on the perception of product's quality, design and prestige, as well as the extent to which these three variables affect consumers' loyalty. The importance of implemented empirical research, unlike others done in Serbia, is reflected in analyzing unified influence of individual variables. It has been noticed that major influence on consumers' behaviour has prestige related to consumption of products from certain countries, following design, while the impact of product's quality was minimal. By applying the empirical model research, it has been confirmed that all defined variables significantly determine consumer's loyalty when it comes to country of origin. By applying one-factor analysis of a variance, it examines whether there is a statistically significant effect of the defined variables on the loyalty, when it comes to different categories of the respondents.
\end{abstract}

Key words: country of origin of products, quality, design, prestige, consumer loyalty.

\section{ЕФЕКАТ ЗЕМЉЕ ПОРЕКЛА ПРОИЗВОДА НА ПРОЦЕС ОСТВАРЕЊА ЛОЈАЛНОСТИ ПОТРОШАЧА}

\section{Апстракт}

Услед све интензивнијег процеса глобализације, ставови и уверења потрошача формирају се под утицајем бројних фактора који се не разматрају у великој мери када је у питању пословање у оквиру националних граница, али могу имати зна- 
чајне импликације на вредновање међународних и глобалних аспеката пословања предузећа. Један од тих фактора јесте и земља порекла из које производи потичу. Иако у области међународног маркетинга постоји већи број радова који испитују проблематику повезаности лојалности потрошача и земље порекла производа, оригиналност истраживања произлази из чињенице да се у овом раду разматра какав је утицај земље порекла производа на лојалност потрошача, не директно, већ посматрано преко одређених карактеристика производа као што су квалитет, дизајн и престиж. Путем регресионе анализе, у раду се испитује утицај земље порекла на перципирани квалитет, дизајн и престиж потрошача, као и то у којој мери ове три варијабле утичу на лојалност потрошача. Значај спроведеног емпиријског истраживања, за разлику од већине постојећих у Србији, огледа се у анализирању обједињеног утицаја појединачних варијабли. Уочено је да највећи утицај на понашање потрошача има престиж повезан са коришћењем производа из одређених земаља, затим дизајн, док је најмањи утицај квалитета производа. Путем дефинисаног модела истраживања утврђено је да све три варијабле значајно одређују лојалност потрошача са аспекта земље порекла. Применом једнофакторске анализе варијансе испитује се да ли постоји статистички значајан утицај дефинисаних варијабли на лојалност када су у питању различите категорије испитаника.

Кључне речи: земља порекла производа, квалитет, дизајн, престиж, лојалност потрошача.

\section{INTRODUCTION}

While doing business within national borders, companies were mainly able to meet the requirements of the local market, without much worry about the endeavors of foreign competitors. However, with the process of globalization which is getting more and more intense, and the emergence of global products, manufacturers in the market are involved in a competitive race with foreign brands as well. It is no longer enough to meet the needs of the local market only, but it is necessary to apply marketing strategies to improve the image of the country from which the products are being sold to foreign markets as well. The time when consumers made decisions about buying products based on their price and quality passed a long time ago. Companies have become aware of the fact that in the era of hyper competition, it is necessary to implement modern technical solutions, as well as promotional activities that would single out the product from the competition. Having in mind that consumers have at their disposal a number of alternatives from which they can choose, their standards increase and it raises awareness about the importance of making the right decisions. Due to the above mentioned factors, consumers are considering a number of elements while opting for a particular product and one of them is the country of origin from which the product comes from. This parameter additionally contributes to the evaluation of products by consumers and their willingness to make a purchase. In the literature, related to the international and global marketing, there is a large number of papers dealing with this issue, i.e. papers that investigate how the country 
of origin affects the creation of customers' loyalty. The image of a country is determined by the cultural, historical, tourist characteristics that contribute to distinguishing the evaluation of the products originating from these countries as well. It is important to note that the country's image is not an unchangeable category, but it is influenced by numerous economic developments. The image of the country of origin usually has an impact in the sense that consumers from developing or less developed countries have a tendency to evaluate the products originating from developed countries as better designed or of a better quality. Bearing in mind that in the numerous papers, from the field of international and global marketing, the impact of the country of origin on consumers' behavior has been identified, in this paper we will be applying the quantitative analysis to examine the effect of the country of origin by three important variables. The aim will be to assess the extent to which the country of origin affects the evaluation of the product by the consumer when it comes to quality, design and prestige of the product for the consumer.

\section{LITERATURE OVERVIEW}

\section{A Conceptual Foundation of the Country of Origin of the Product}

Due to the efforts of companies to position themselves in the minds of consumers and ensure the leading position in the market, in the marketing literature, during the past years the subject of research by many authors was the country of origin (Heslop, 2008; Rakita, B, 2012; Yang, Wang, Fetscherin, 2010). With the appearance of a growing number of global brands, consumers often tend to evaluate certain products based on the country from which they originate (Roth, Romeo, 1992) Thus, it is very important to consider the overall factors that determine the image of the country, such as economic, political, cultural, legal environment, the characteristics of the population or technological development. The country of origin is usually communicated with the label "made in" and it refers to the perception of consumers about that country, which affects their evaluation of the product or service that originates from it (Chapa, Minor, 2006). For the countries in the international environment it is necessary to take into consideration a number of specific conditions that exist in a given environment (Šapić, Jovanović, Furtula, 2009), recognition of a product which reflects a particular country of origin can influence the improvement of its image and reputation as well. In the marketing literature, as synonyms for the country of origin certian names are given, such as "country of design" or "country of origin" (Rezvani, Dehkordi, Rahman, Fouladivanda, Habibi \& Eghtebas, 2012). Due to the increasing complexity of the given concepts and inability for their precise distinctions, the designation of the country of origin in the global environment is difficult to define. Nowadays, there is an increasing number of multinational companies operating in the 
global market and products whose components are constructed from the parts originating from different countries. For the purpose of this paper, we will not be emphasizing the difference between the country of production and the country in which the product is branded, but we will reduce these categories to the concept of country of origin, although their distinction may have significant implication for consumer behavior (Fetscherin \& Toncar, 2010). In the absence of reliable and relevant information about the products that consumers have a tendency to use, the country of origin represents a guideline which contributes to making their purchasing decisions. Many authors point out that there are certain stereotypes that are related to a particular country of origin of products, which provide emotional and symbolic value and inspire confidence to consumers (Botsch \& Hemettsberger, 1998). The components of the image of the country are numerous, and some of the basic ones are the following (Heslop, Lu \& Cray, 2008):

- Political and social character of the country - political stability, the degree of democracy, the level of rights, quality of life;

- The degree of industrialization, technological development, economic stability;

- Character of the population of the country, such as the degree of confidence, friendliness, kindness;

- The presence of foreign direct investment, aspects of the tourism, cultural and economic environment.

As consumers may be loyal in buying branded products, in the same way their loyalty can be attributed to the effects of the country of origin. Moreover, many authors have investigated this issue, and found that the interdependence of association and brand loyalty can be brought into direct contact with the country in which the given brand exists (Pappu, 2007). Previous research has found that the country's image significantly changes when the location of the products that cause positive associations towards a given destination changes. Thus, for example, it was found that the brand image of Japanese car was significantly undermined when its country of origin relocated to South Korea (Ille \& Chailan, 2011). If consumers do not have a lot of experience with the products from that country of origin, halo effect can influence the formation of their beliefs, and if you are already familiar with products from a particular country of origin, halo effect (Han, 1989) determines their existing attitudes about the products, which is transmitted to other consumers. Therefore, this effect can be very present, so it is recommended that while launching new products, the country of origin should be emphasized, in the case it causes positive associations with consumers for products of similar categories and use of value.

Due to increasing competition in global trends, for the country of origin of certain products it is very important to understand the fact that the image of the country can be changed, at a faster or slower pace (Heslop et al., 
2008), that it is the category, which, in a similar manner as the product or service, may be subject to numerous modifications. It is necessary that the creators of the various economic events and macroeconomic trends also be aware of the effect that the country of origin has on the economy of a country and its positioning in the international market. However, sometimes the image of the country of origin may change due to unforeseen events, economic and stabilization policy, but also improve if the number of foreign direct investments in the country increases or it becomes the venue of some important world events. In addition to the economic development of a country, for the evaluation of products originating from it, one may also consider the characteristics of the population, because the emotional aspect of consumer awareness plays a crucial role.

Due to the increased presence of companies on the international and global markets, resources are increasingly being moved to other countries. However, it is a more common phenomenon that the products are created as a set of components from different countries, which complicates their recognition and connection to the correct country of origin.

For the affirmation of global brands that are available on the global market and that contribute to the profit and prosperity of companies that launch them (Bengtsson, Bardhi \& Venkatraman, 2010) the country of origin is the criterion by which consumers form their attitudes and beliefs. There are different conclusions obtained during the studies of relevant literature in international research. Although most authors emphasize the interdependence between the country of origin of products and the intention of the consumer to make a purchase (Elliot\&Cameron, 1994; Kalicharan, 2014) it should be carefully approached to the study of these effects, bearing in mind that consumers react differently depending on previous experience with the use of products from certain countries. The way they perceive a particular country of origin, will also depend on their knowledge of the characteristics and performance of products, so that the level of their previous experience affects how they will assess the specific country of origin (Pecotich \&Ward, 2007). According to some research, the country of origin has a significant impact on the consumer's decision regarding to products in which there is a high level of involvement, in relation to those products in which the level of involvement is somewhat lower (Srikantanyoo \& Gnoth 2002, cited in Raharjo, 2012), which is understandable, bearing in mind that when buying such products usually the cognitive dissonance is higher, and consumers enter the phase of concern when considering whether they made the right decision. In addition to the information available concerning the price and brand name, considering the country of origin when it comes to quality of products and level of customer loyalty contributes to a better product positioning and recognition of manufacturers in the global market. 


\section{The Effect of the Country of Origin on the Loyalty of the Customers}

The concept of customer loyalty in marketing is an object of everyday research, having in mind that consumers who are loyal to the company are the key for the success of the economy. Consumer loyalty is defined as devotion to brands or business environment and it is reflected in their willingness to re-do the purchase of the same product (Marinković, 2012, p. 144). Loyal consumers contribute to the achievement of a number of benefits from the point of view of the companies, thus reducing marketing costs, are less price sensitive, but are familiar with the products that they use, but do not require additional resources (Rowley, 2005, cited in Zakaria et al., 2013). Consumer behavior is defined by a number of demographic, emotional and price factors, so in the condition of the intense competition it is difficult to maintain their attention.

Recently, there is an increasing number of papers in international marketing which are trying to examine the interdependence between countries of origin and consumer behavior, and trying to determine whether re-purchase and consumer favour can be brought in connection to the country of origin from which the product originates (Ling, 2013). Consumer behavior and their loyalty is greatly influenced by political, legal, social environment, as well as personal characteristics and shopping habits (Thomson, Pollio \& Locander, 1994). As the process of globalization has enabled producers to operate in the markets of many countries, consumers, in the selection of brands and products, are trying to identify the country from which the product comes and accordingly make the decision to purchase. For products with a high level of involvement, it often happens that in the presence of global brands, they perceive those brands as of better quality, whereas local brands are put in the second place. Thus, many authors (Iftekhar \& Muhammad, 2015) tend to test which performances characterize domestic and which characterize foreign brands, and what factors contribute to the fact that global brands are perceived as of higher quality. For consumers, country of origin often has the function of one of the attributes of a product that affects the formation of their attitudes and preferences when it comes to product quality. According to some researches, even the country of origin of developed countries can have a greater impact on consumers' decisions and on gaining their loyalty, more than the price or value of the brand (Kalicharan, 2014, p. 899). However, a unique answer to what amount of the impact the country of origin has on consumers' behavior cannot be given, because this is an issue that often depends on the economic development of the country, but also on the personal characteristics of consumers, as well as on the social and cultural environment. Namely, from time to time, it happens that consumers differently perceive products that originate from the same country, because, if the country is well assessed in terms of eg. fashion products, it does not necessarily mean that there is a consistency of consumer 
attitudes towards the technological characteristics of products from that country.

Customers often perceive the product quality on the basis of the country of origin (Hamzaoui Essoussi, Merunka, 2006; Kalicharan, 2014; Saydan, 2013). Therefore, precisely the quality is one of variables through which the customer loyalty would be examined, i.e. on the basis of conducted research, it would be identified to what extent products from certain countries contribute to consumer loyalty due to its quality.

For some countries, the recognizable product design is distinctive, or so to say some of the features such as style, variety of colors, and great number of models (Nagashima, 1977; Rakita, 2012). In this paper, it would be examined whether mentioned relation influence customer loyalty.

Also, based on the paper reviews and conclusions of certain authors, it has been identified that there is a connection between self-verification of personal identity, or prestige and involvement of customers in buying certain products (Islam \& Aktar, 2013). Design and prestige may be important features when consumers consider purchase decision (Roth, Romeo, 1992). With emphirical research it would be determined whether this correlation is distinctive when observing the customer country of origin.

When creating a marketing strategy, marketers should take into account the level of consumer familiarity with a particular country of origin, and accordingly form their own marketing strategy, by focusing on how consumers perceive the quality of the product from the point of view of the origin of the country, but also in terms of competitive products (OzreticDozen, Skare \& Krupka, 2007). In recent years, the effect of the country of origin is increasingly cited as an indicator for evaluating the quality of products (Ozretic et al., 2007):

- With the rapid process of globalization, many consumers use country of origin as help for finding information about products; treating it as an indicator of the quality and acceptability;

- The increasing complexity of products as well as their standardization, lead marketers to use the concept of country of origin in order to achieve recognition in the global market;

- The effect of country of origin provides great opportunities for the formulation of an international marketing strategy;

- Consumers are easier to adapt to foreign products and gain favour towards them.

Country of origin can have a positive or negative impact on the process of making decisions and choices of consumers, and their actual behavior. The effect of country of origin can affect consumers' choice, in addition to other criteria such as quality, price, design that contribute to the recognition and product's consuming.

In the study of influence of the country of origin, an especially important aspect is the tendency of consumers to consume domestic 
products, considering that in this way they contribute to the development of the country in which they live. Ethnocentrism contributes to a negative evaluation of foreign products, believing that in this way, the local economy of the country is distorted and also that the other countries in the global environment have the benefit. However, some studies have shown that consumer's ethnocentrism depends not only on national stereotypes, but on product's category as well. In that way, for example, consumers may exhibit a tendency towards the purchase of one category of products from a particular country, but to characterize the purchase of other product groups from the same country as of insufficient quality (Balabanis \& Diamantopoulos, 2004). In the paper, we do not analyze the specific category of products in relation to which the effect of the country of origin is examined, but our goal is to gain more general picture of whether the country of origin affects the consumer without apostrophizing what type of product it is. If the consumer does not have previous experience of using the product, he will make his own assessment of the product based on the evaluation of other criteria, such as the information obtained through oral propaganda or promotional activities. While considering the impact that the country of origin has on consumer's loyalty, it is important to understand the cognitive process, or whether the information about the country of origin is already placed in their internal memory. If the answer is yes, the country of origin will prompt them to think that this is one of the factors that may influence their purchase (Laroche, Papadopoulos, Heslop, Mourao, 2005).

\section{AN EMPIRICAL RESEARCH OF THE EFFECT OF THE COUNTRY OF ORIGIN ON THE CONSUMER'S LOYALTY}

\section{Research Methodology}

The subject of research in this paper is to examine the link between the country of origin of products and customer's loyalty. The main objective of the research is to get the relevant information on whether the country of origin affects consumer's loyalty, while an aim is to determine how individual parameters (product quality, design and prestige) from a particular country of origin affect consumer loyalty. Bearing in mind that in most of the papers in the field of marketing, the effect of the country of origin was considered in relation to parameters such as quality, design, prestige (Chowdhury \& Ahmed, 2009; Rakita, 2012; Yang, Wang, 2008) our questionnaire was structured to determine which of these characteristics influence consumers' behavior the most. Accordingly, in addition to general information on subjects regarding gender, age, degree of education and income, the questionnaire includes 18 statements which are related to the country of origin. Respondents expressed their level of agreement in the questionnarire through a five-point Likert scale (number 1 - I strongly 
disagree, number 5 - I strongly agree), which is one of the most commonly used in these studies.

The quality of the product was analyzed by observation of the first five statements (Jakpar \& Na, 2012). Product design is analyzed through statements 6-10 (Rakita, 2012; Roth\& Romeo, 1992), while the prestige of consumers regarding the use of products from the country of origin is evaluated through statements 11-15 (Roth et al., 1992; Zeb, Rashid \& Javeed, 2011). The loyalty of consumers towards products from the country of origin in question was tested through statements 15-18 (Marinkovic, 2012).

In accordance with the defined object and the purpose of the research, the authors tested three hypotheses:

1. When evaluating product's country of origin, the quality of product has statistically significant and positive influence to customer loyalty.

2. When evaluating product's country of origin, the design of the product has statistically significant and positive influence to to customer loyalty.

3. When evaluating product's country of origin, prestige which arises with the use of those products has statistically significant and positive impact to customer loyalty.

In order to examine the relationship between the observed variables, in the paper, all three hypotheses were tested by using descriptive statistics, correlation analysis and simple and multiple regressions. Data analysis was performed in a statistical program for the Social Sciences (The Statistical Package for the Social Sciences-SPSS, version 21).

\section{RESULTS OF THE RESEARCH}

In order to test whether the country of origin has an impact on the rate of repeated purchases of consumers and on creating their loyalty, an empirical research was conducted using the method of interview, techniques of the questionnaire. Data was collected in the period from 20.0627.07.2017. The questionnaire was distributed to respondents in electronical and printed form. Out of 160 delivered questionnaires, 123 of them were valuable (response rate was $76.88 \%$ ). Demographic profiles are presented in Table 1. 
Table 1 Demographic structure of the participants $n=123$

\begin{tabular}{lcc}
\hline Demographic profile & Frequency & $\%$ \\
\hline Gender & 48 & 39 \\
$\quad$ Male & 75 & 61 \\
Female & & \\
Age & 6 & 4,9 \\
$18-24$ & 40 & 32,5 \\
$25-31$ & 16 & 13 \\
$32-38$ & 22 & 17,9 \\
$39-45$ & 15 & 12,2 \\
$46-52$ & 17 & 13,8 \\
$53-59$ & 7 & 5,7 \\
60 and more & & \\
Education & 22 & 17,9 \\
High school & 22 & 17,9 \\
Higher education & 79 & 64,2 \\
College education & & \\
Employment status & 14 & 11,4 \\
Student & 12 & 9,8 \\
manager, entrepreneur & 20 & 16,3 \\
professor, doctor, engineer & 55 & 44,7 \\
Clerk & 16 & 13 \\
Worker & 1 & 0,8 \\
Retiree & 5 & 4,1 \\
Other & &
\end{tabular}

Source: Calculation based on SPSS

By observing Table 1, we can see that in the age structure of the respondents, participation of the women in the study is higher $(61 \%)$, while men are represented in the sample with 39\%. Most of them belong to the category that includes a range of 25-31 years. The smallest number of respondents aged between 18 and 24 years (4.9\%) and 60 and over (5.7\%). In accordance with the level of education, it can be seen that in the sample, up to $64.2 \%$ of respondents has college degree, while the number of respondents with high school and higher education is the smallest and equal, and it totals to $17.9 \%$. In the structure of the sample, a clerk is a job that is circled in $44.7 \%$ of the cases, while retirees are the rarest $(0.8 \%)$. In the initial step of the analysis, in order to determine the homogeneity / heterogeneity of opinions of respondents, we calculated the value of arithmetic mean and standard deviation for each statement. The results are presented in Table 2. 
Table 2 Values of the descriptive statistics (arithmetic average and standard deviation) for listed statements

\begin{tabular}{|c|c|c|}
\hline Findings & $\mathrm{M}$ & SD \\
\hline \multicolumn{3}{|l|}{ Quality } \\
\hline $\begin{array}{l}\text { The country of origin has a great impact on you when it } \\
\text { comes to product quality. }\end{array}$ & 4,13 & 0,799 \\
\hline $\begin{array}{l}\text { The country of origin has a great impact on you when it } \\
\text { comes to product reliability. }\end{array}$ & 4,15 & 0,827 \\
\hline $\begin{array}{l}\text { The country of origin has a great impact on you when it } \\
\text { comes to product durability. }\end{array}$ & 4,12 & 0,845 \\
\hline $\begin{array}{l}\text { The country of origin has a great impact on you when it } \\
\text { comes to product performances. }\end{array}$ & 3,93 & $\mathbf{0 , 7 8 7}$ \\
\hline $\begin{array}{l}\text { The country of origin has a great impact on you when it } \\
\text { comes to product functionality. }\end{array}$ & 3,85 & 0,897 \\
\hline \multicolumn{3}{|l|}{ Design } \\
\hline $\begin{array}{l}\text { Products from a particular country of origin are } \\
\text { characterized by a distinctive design. }\end{array}$ & 3,73 & 0,959 \\
\hline $\begin{array}{l}\text { Products from a particular country of origin are } \\
\text { characterized by modern technical solutions. }\end{array}$ & 4,05 & 0,886 \\
\hline $\begin{array}{l}\text { Products from a particular country of origin are } \\
\text { characterized by a distinctive style of the product. }\end{array}$ & 3,74 & 0,922 \\
\hline $\begin{array}{l}\text { Products from a particular country of origin are } \\
\text { characterized by a distinctive slogan and logo. }\end{array}$ & 3,68 & 0,917 \\
\hline $\begin{array}{l}\text { Products from a particular country of origin are } \\
\text { characterized by a great number of models and colours. }\end{array}$ & 3,58 & 0,958 \\
\hline \multicolumn{3}{|l|}{ Prestige } \\
\hline $\begin{array}{l}\text { The use of products from a particular country of origin } \\
\text { gives me satisfaction. }\end{array}$ & 3,67 & 1,053 \\
\hline $\begin{array}{l}\text { The use of products from a particular country of origin } \\
\text { makes me recognizable in the society. }\end{array}$ & 3,13 & 1,016 \\
\hline $\begin{array}{l}\text { The use of products from a particular country of origin } \\
\text { contributes to my style. }\end{array}$ & 3,23 & 1,062 \\
\hline $\begin{array}{l}\text { The use of products from a particular country of origin } \\
\text { increases my self-confidence }\end{array}$ & 2,88 & 1,021 \\
\hline $\begin{array}{l}\text { The use of products from a particular country of origin } \\
\text { makes me happy }\end{array}$ & 3,06 & 1,002 \\
\hline \multicolumn{3}{|l|}{ Loyalty } \\
\hline $\begin{array}{l}\text { If I am satisfied with the products from a particular } \\
\text { country of origin, I will continue buying them in the } \\
\text { future. }\end{array}$ & 3,87 & 0,829 \\
\hline $\begin{array}{l}\text { I am ready to share my satisfaction with the products } \\
\text { from a certain country with other people. }\end{array}$ & 3,86 & 0,833 \\
\hline $\begin{array}{l}\text { I am ready to pay more for the products from certain } \\
\text { countries which fulfilled my expectations. }\end{array}$ & 3,76 & 0,813 \\
\hline
\end{tabular}

Source: Calculation based on SPSS 
By interpretating the values of descriptive statistics, or arithmetic mean and standard deviation, it can be seen that based on the values of these indicators, respondents generally believe that all three factors related to the country of origin have an impact on their behavior when purchasing. The highest values of arithmetic means were reported in a statement referring to the statements that the country of origin has an impact on consumers when it comes to product reliability (mean 4.15), quality (mean 4.13), as well as their durability (mean 4.12). The minimum value of the arithmetic mean was observed when it comes to the statement that refers to the fact that the use of products from a particular country increases consumers' confidence (mean 2.88). The most homogeneous attitudes of respondents are observed with the statements that the country of origin has an impact on the respondents when it comes to product performance (standard deviation 0.787), while the highest heterogeneity was observed in claims relating to the fact that the country of origin contributes to their style (standard deviation 1.062).

Since all statements are grouped into 3 variables that are related to the country of origin, i.e. the first 5 statement reflect the quality, the second 5 statements reflect design, third 5 statements reflect prestige, and the last 3 consumers' loyalty, for all of these groups Cronbach's alpha coefficient was calculated, to determine the reliability and internal consistency of claims. The value of this coefficient for quality, design and prestige is above 0.7 which indicates to adequate reliability and consistency of the statements (Cohen, 1988 in Pallant \& Nunnaly 1978), while the loyalty is above 0.6 which also could be acceptable value (Robinson, Shaver \& Wrightsman, 1991). Cronbach's alpha for the entire model is 0.856 .

\section{Table 3 Value of Cronbach's alpha coefficient}

\begin{tabular}{lc}
\hline Variable & Cronbach's alpha \\
\hline Quality & 0,794 \\
Design & 0,701 \\
Prestige & 0,844 \\
Loyalty & 0,624 \\
\hline
\end{tabular}

Source: Calculation based on SPSS

Before we applied a regression analysis, the correlation analysis had been performed. The results of the Pearson coefficient (Table 4) were presented, where it was noted that there was a statistically significant association among all the variables, except that it is mainly of moderate intensity. As the correlation coefficient for two independent variables is in relation to loyalty, as an dependent variable in the range from 0.3 to 0.49, we can conclude that there is a connection medium (Cohen, 1988 in Pallant, p. 137) between design and prestige, as the independent variables that are related to the country of origin and loyalty of the consumers as 
the dependent variable. The strongest correlation is between product design from a specific country of origin and loyalty, where the correlation coefficient is 0.432 .

Table 4 Inter-Correlation matrix

\begin{tabular}{lcccc}
\hline Variable & 1 & 2 & 3 & 4 \\
\hline Quality & 1 & $0,425^{* *}$ & $0,294^{* * *}$ & $0,293^{*}$ \\
Design & $0,425^{* *}$ & 1 & $0,368^{* *}$ & $0,432^{* *}$ \\
Prestige & $0,294^{* *}$ & $0,368^{* *}$ & 1 & $0,390^{* *}$ \\
Loyalty & $0,293^{* *}$ & $0,432^{* *}$ & $0,390^{* *}$ & 1 \\
\hline \multicolumn{5}{c}{ Correlation is significant on the level of 0,01 } \\
& Source: Author's calculation based on SPSS
\end{tabular}

After the correlation analysis, we used regression analysis to examine which of the variables in question had a significant impact on consumers' loyalty. So, as the independent variables we used quality of the product, design and the prestige associated with the countries of origin, while consumer loyalty was a dependent variable. The results of simple regression analysis are presented in Table 5.

Table 5 Results of the simple regression analysis

\begin{tabular}{lcccc}
\hline Variables & $\beta$ & $\mathrm{T}$ & Sig. & $\mathrm{R}^{2}$ \\
\hline Quality & 0,250 & 2,835 & $0,005^{* * *}$ & 0,062 \\
Design & 0,412 & 4,968 & $0,000^{* * *}$ & 0,169 \\
Prestige & 0,487 & 6,136 & $0,000^{* *}$ & 0,237 \\
\hline
\end{tabular}

Note: $\mathrm{p}<0,01$

Source: Author's calculation based on SPSS

As it can be seen from Table 5, all variables have an impact on consumers' loyalty when it comes to the notion "country of origin". Therefore, design of products from a particular country of origin, products quality, as well as the prestige during their use affect consumers' loyalty ( $p$ value for all variables is less than 0.01 ).

By analyzing table 5, all three defined hypotheses for this study were tested:

1. When evaluating product's country of origin, the quality of product has statistically significant and positive influence to customer loyalty -CONFIRMED,

2. When evaluating product's country of origin, the product design has statistically significant and positive influence to customer loyalty - CONFIRMED,

3. When evaluating product's country of origin, prestige which arises with the use of those products has statistically significant and positive impact to customer loyalty - CONFIRMED. 
The greatest impact on consumer loyalty has a prestige associated with the countries of origin, $(\beta=0,487, t=6,136, p=0,000)$, while smaller impact on consumers' loyalty has a quality of the product that binds to a particular country of origin $(\beta=0,250, t=2,835, p=0,005)$.

In order to analyze the impact that all three variables from a specific country of origin (quality, design and prestige) have on consumer loyalty, multiple regression was applied. In the application of the multiple regression analysis, a problem of multicollinearity often occurs when independent variables influence each other and make it difficult to assess the impact of each independent variable on the dependent variable. For this reason, variance inflation factor was presented (VIF). Its value is less than $10(1.254$ for quality, 1.325 for design, and 1.189 for prestige) for all three variables in the model, which indicates that there is no problem of multicollinearity (Cohen, 1988 in Pallant, J, 1988). Some statisticians indicate that the VIF value is higher than 5 signal multicollinearity (Field, 2000) so that a significantly lower value in the research is an indicator that there is no issue of multicollinearity. The results of multiple regression analysis are presented in Table 6. The coefficient of determination for the entire model is 0.300 , which means that $30 \%$ of the variability of customers' loyalty is under the influence of the three variables from a specific country of origin (quality, design and prestige), while $70 \%$ is under the influence of other factors. For this kind of field research, the coefficient of determination is satisfactory and it is on the similar level as in the papers that deal with similar issues (Hamzaoui Essoussi et al, 2006).

Table 6 Results of the multiple regression analysis

\begin{tabular}{lcccc}
\hline Variables & $\beta$ & T & Sig. & VIF \\
\hline Quality & 0,027 & 0,309 & 0,758 & 1,254 \\
Design & 0,259 & 2,934 & 0,004 & 1,325 \\
Prestige & 0,384 & 4,593 & 0,000 & 1,189 \\
\hline
\end{tabular}

Source: Author's calculation based on SPSS

Based on the table 6 , it can be determined that a design of the product related to the certain country of origin has a statistically significant effect on consumers' loyalty $(\beta=0,259, \mathrm{t}=2,934 \mathrm{p}=0,004)$, as well as prestige for consumers while using the product from a particular country of origin $(B=0,384, t=4,593, p=0,000)$, while the quality of product from a particular country of origin does not have statistically significant effect on consumers' loyalty. 


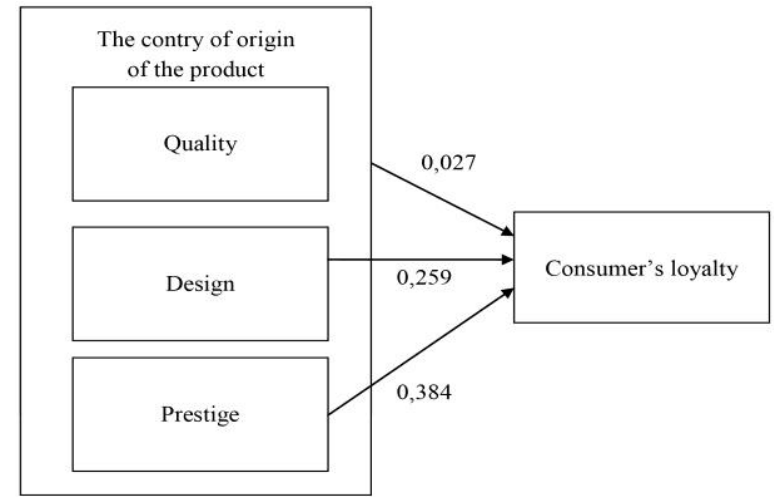

Figure 1 The effect of the observed variables on the loyalty of the consumers Source: Author's calculation

In order to identify whether there is a statistically significant difference between the different categories of respondents (classified by gender, age, employment status and education) regarding their loyalty to the products from a specific country of origin, we applied one-factor analysis of variance in the paper. ANOVA results are explained below (Table 7)

Table 7 The results of the one-factor analysis of the variance

\begin{tabular}{llcr}
\hline Age of the respondents & $\begin{array}{c}\text { Difference in } \\
\text { mean value }\end{array}$ & Sig \\
\hline $18-24$ & $25-31$ & -2.000 & .271 \\
& $32-38$ & -1.438 & .752 \\
& $39-45$ & -1.682 & .545 \\
& $46-52$ & -1.500 & .721 \\
& $53-59$ & $-2.971^{*}$ & .038 \\
$53-59$ & 60 and higher & -.357 & 1.000 \\
& $18-24$ & $2.971 *$ & .038 \\
& $25-31$ & .971 & .643 \\
& $32-38$ & 1.533 & .314 \\
& $39-45$ & 1.289 & .435 \\
& $46-52$ & 1.471 & .386 \\
Education of the respondents & 2.613 & .068 \\
\multirow{4}{*}{ High school } & 60 and more & Difference in & Sig \\
& higher education & mean value & \\
College & College & -1.136 & .153 \\
& high school & $-1.633 *$ & .003 \\
& higher education & $1.633^{*}$ & .003 \\
& Note: The loyalty & .497 & .565 \\
\hline
\end{tabular}

Note: The loyalty of customers is a dependent variable; the difference among groups was statistically significant at the 0.05 level; ANOVA results are presented only for one group of subjects among which there is a statistically significant difference

(when it comes to the age and education) 
Respondents were first divided into two groups according to the gender (group 1-men, group 2-women). After that, we used a single factor analysis of variance to examine the influence of these two groups on consumer loyalty, which is the dependent variable, towards the products from a specific country of origin of the product. It was identified that there was no statistically significant difference between men and women when it comes to their loyalty $(\mathrm{p}=0.156>0.05)$.

By using one-factor analysis of variance, we examined the effect of the age of the respondents to the level of their loyalty. Respondents were divided into seven groups (group 1: 18-24 years, group 2: 25-31 years, group 3: 32-38 years, group 4: 39-45 years, group 5: 46-52 years, group 6: 53-59 years old, and group 7: 60 or more years). When it comes to the age of respondents, the amount of the significance for the Levene's test is $0.335>0.05$, which indicates that the assumption of homogeneity of variance is not undermined. There was a statistically significant difference between different age groups when it comes to consumers' loyalty $(\mathrm{p}=$ $0.023<0.05$ ). Since the difference we obtained was statistically significant, we analyzed the results of subsequent tests. Subsequent comparisons by using Tukeyev HSD test indicated that the mean value of the group $1(\mathrm{M}=$ $10.5, \mathrm{SD}=2.074)$ and group $6(\mathrm{M}=13.47, \mathrm{SD}=1.586)$ is significantly different, i.e. there is a statistically significant difference between respondents aged 18-24 years and 53-59 years when it comes to consumers' loyalty towards products from a specific country of origin, while in other groups there was no statistically significant difference.

When it comes to the level of education of the respondents, after we divided them into four groups (Group 1-primary education, group 2-high school, group 3-higher education, group 4-College) we examined whether there is a statistically significant difference between these groups and consumers' loyalty. The size significance of Levene's test is $0.265>0.05$, indicating that the assumption of homogeneity of variance has not been violated. The value of $p=0.04$ indicates that there is a statistically significant difference compared to subsequent tests, i.e. by applying Tukeyev HSD test, we showed that the mean value of the group $2(\mathrm{M}=11.00, \mathrm{SD}=2.390)$ was significantly different from group $4(\mathrm{M}=12.63, \mathrm{SD}=1.909)$.

Taking into consideration the employment status of the respondents, by one-factor analysis of variance it was found that there was no statistically significant difference between the respondents who were divided into groups (group 1-students, group 2-entrepreneurs, 3- professors, 4-clerks, 5-worker, 6-retirees, 7- etc.) and consumers' loyalty towards products from a specific country of origin of the product $(p=0.313>0.05)$. 


\section{CONCLUSION}

As it is illustrated in the paper, the country of origin has an impact on consumers' loyalty when it comes to all three variables. Contribution of research reflects in explanation of consumers' loyalty according to country of origin, by using three variables (quality, design and prestige). Although all variables were analyzed separately, unified review points out their importance in marketing literature.

In the conditions of increased globalization and competition, companies should take into account the diversity of consumers' desires and also that, while satisfying the needs and demands of consumers, they should become aware of the fact that the origin of the product is one of the epithets that improves the placement of products on the market.

However, the results of multiple regression analysis show that, when it comes to the country of origin, the customer loyalty is mostily influenced by the statements connected with the prestige which resulted from the use of products, i.e. self-verification of personal identity with the use of products from different countries. This phenomenon is the subject of research in the field of customer behavior, that is, the attention dedicated to the information about social comparison - ATSCI (Babin \& Harris, 2012, p. 177.) could have great implications to customer loyalty. Thus, this characteristics are manifested in such way that customers use products from particular country of origin because in this way they contribute to the personal affirmation and with the use of these products they adapt to the expectations of others. Product design is rightfully considered one of the most important determinants of the country of origin (Rakita, 2012). Bearing in mind that, according to the results of research, product design is one of the most important criteria when considering products originating from certain countries, some future research could examine the differences in the perception of consumers between the country of origin of product and country of design of product. Product design is rightly considered as one of the most significant determinant of country of origin (Nagashima, 1977). Although respondents gave high marks to the characteristics related to the quality of the product, it is not highly associated with their loyalty. One of the reasons could be that for the perception of the quality of products by consumers, price is essential, in most of the cases. Numerous authors have confirmed hypothesis that refer to the connection of country of origin and quality of product (Hamzaoui Essousi et al., 2006; Saydan, 2013), Also, it is found that product category is important for the perception of quality of products from certain countries (Roth, Romeo, 1992), or complexity of design and production, that is for more complex products the effect of country of origin is greater (Hamzaoui Essoussi et al., 2006), so that in the future research different product categories should be considered. This work is a contribution to the scientific and professional literature in the sense that there is a small number of domestic papers that 
show the importance of criteria such as quality, design and prestige of certain products originating in the country of origin of consumer loyalty. In the most cases, researches are reduced to consideration what kind of impact the country of origin has on consumers' behavior in relation to other criteria, such as price, quality or brand. Also, the analysis in this area includes mainly the comparison of different countries in terms of valorisation of products originating from them. Low coefficient of determination in the paper shows that, except for the country of origin, some other criteria has impact on the evaluation, so future analysis could be based on an evaluation of the economic, demographic, social and cultural specificities of countries.

One of the shortcomings of the research is a small sample, as well as the limitations of the research only to the territory of Kragujevac. In order to identify customers' loyalty according to the criteria such as quality, design and prestige, a comparison among consumers in developed and less developed countries should be made, and it should be identified whether the level of development of the country has implications on consumers' evaluation of global products. Also, some of the future research could identify the degree of loyalty towards the specific countries whose products are most common in our market, as well as towards certain categories of the products. In fact, it would be preferable to examine the consumers' loyalty towards products from a given country of origin depending on parameters such as: durability of products, their purpose, method of use, all of which can affect different perception and evaluation by consumers. Although the aim of the study was to determine the overall level that the country of origin has on consumers' behavior when it comes to quality, design and prestige to the consumer, the implementation of factor analysis in a future research could identify another criteria that may influence the perception of the product from a given country of origin, such as, for example, innovation. It should also be considered whether there is a causal relationship between the previously available information for the consumers about the level of economic development of the countries from which the products originate, and their willingness to continue to carry out the purchase of the product.

\section{REFERENCES}

Babin, B., Harris, E. (2012). Ponašanje potrošača [Consumer behaviour], Data Status, Beograd

Balabanis, G, Diamantopoulos, A. (2004). Domestic Country Bias, Country- of-Origin Effects, and Consumer Ethnocentrism: A Multidimensional Unfolding Approach, Journal of the Academy of Marketing Science, Vol 32, No1., 80-95, DOI: $10.1177 / 0092070303257644$

Bengtsson, A, Bardhi, F., Venkatraman, M. (2010). "How global brands travel with consumers", International Marketing Review, Vol. 27, Iss 5, 519 - 540, https://doi.org/10.1108/02651331011076572 
Botschen, G., Hemettsberger, A. (1998). "Diagnosing means-end structures to determine the degree of potential marketing program standardization", Journal of Business Research, Vol. 42, No. 2, 151-9, https://doi.org/10.1016/S0148-2963(97)00116-1

Chapa, S., Minor, M. S., \& Maldonado, C. (2006). "Product category and origin effects on consumer responses to counterfeits: comparing Mexico and the U.S.", Journal of International Consumer Marketing, Vol. 18 No. 4, 79-99.

Chowdhury, K.,H., Ahmed, J.U. (2009). An examination of the effects of partitioned country of origin on consumer product quality perceptions, International Journal of Consumer Studies, 496-502, DOI: 10.1111/j.1470-6431.2009.00783.x

Cohen, J.W. (1988). Statistical power analysis for the behavioral sciences ( 2 nd edn), Hillsdale, NJ:Lawrence Erlbaum Associates, u Pallant, J. (2011), SPSS Priručnik za preživljavanje, Mikro knjiga, Beograd

Elliot, G, Cameron, R., (1994). Consumer Perception of Product Quality and the Country of origin effect, Journal of International Marketing, Vol.2, No.2, 4962, ISSN 1069-031X

Hamzaoui Essoussi, L., Merunka, D. (2006). The impact of country of design and country of manufacture on consumer perception of bi-national product's quality: An empirical model based on the concept of fit, Journal of Consumer Marketing, 23/3, 145-155, DOI: 10.1108/07363760610663303

Fetscherin, M., Toncar, M (2010). The effects of the country of brand and the country of manufacturing of automobiles, An experimental study of consumers' brand personality perceptions, International Marketing Review, Vol. 27, Iss 2, $164-$ 178, https://doi.org/10.1108/02651331021037494

Field, A. (2000). Discovering statistics using SPSS for Windows. USA: Sage Publication.

Han, M, (1989). Country Image, Halo or Summary Construct, Journal of Marketing Research, Vol. 26, 222-229

Heslop, L., Lu, I., \& Cray, D. (2008). "Modeling country image effects through an international crisis", International Marketing Review, Vol. 25, Iss: 4, 354 - 378, DOI 10.1108/02651330810887440

Iftekhar, A. (2015). Impact of Product'S Country of Origin on Consumer Buying Behavior (Case Study of Beauty Care Products), European Journal of Business and Management., 7, No.1, 127-137

Ille, F., Chailan, C. (2011). Improving global competitiveness with branding strategy Cases of Chinese and emerging countries' firms, Journal of Technology Management in China, Vol 6, Iss. 1, 84-96, https://doi.org/10.1108/17468771111105677

Islam, M.S., Aktar, S. (2013). Role of Brands on Consumer's buying behavior in Bangladesh: a study on fashion cloth, European Journal of business and management, Vol. 5, No12, 164-174, ISSN 2222-2839

Jakpar, S., Na, A. (2012). Examining the Product Quality Attributes That Influences Customer Satisfaction Most When the Price Was Discounted: A Case Study in Kuching Sarawak, International Journal of Business and Social Science, Vol. 3 No. 23; December 2012, 221-236

Kalicharan, H. (2014). The Effect and Influence of Country-Of Origin On Consumers' Perception Of Product Quality And Purchasing Intentions. Nova Southeastern University, International Business \& Economics Research Journal, Volume 13, Number 5, 898-902

Laroche, M., Papadopoulos N., Heslop, L., \& Mourali, M. (2005). The influence of country image structure on consumer evaluations of foreign products, International Marketing Review, Vol 22, No1, 96-115, https://doi.org/10.1108/ 02651330510581190

Ling, L. (2013). The Relationship between Global Brand and Country of Origin in Chinese Consumption Market, International review of business, 13, 87-112 
Marinković, V. (2012). Marketinški aspekti satisfakcije i lojalnosti IMarketing aspects of satisfaction and loyalty], Orijentacija na potrošače $u$ savremenom bankarskom poslovanju, Ekonomski fakultet Univerziteta u Kragujevcu

Nagashima, A. (1977). "A Comparative "Made In" Product Image Survey among Japanese Businessmen", Journal of Marketing, 41 (3), 95-100, DOI 4996457

Nunnally, J. C. (1978). Introduction to Psychological Measurement. New York: McGrawHill.

Ozretic-D, Skare, V., \& Krupka (2007). Assessments of country of origin and brand cues in evaluating a Croatian, western and eastern European food product, Journal of Business Research, 60, 130-136, doi:10.1016/j.jbusres.2006.10.011

Pappu, R., Quester, P., \& Coonsey, R. (2007). Country image and consumer-based brand equity: relationships and implications for international marketing, Business Studies 38, 726-745, https://doi.org/10.1057/palgrave.jibs.8400293

Pecotich, A., Ward, S. (2007). Global branding, country of origin and expertise, International Marketing Review, Vol. 24, Iss 3, 271 - 296, https://doi.org/10.1108/ 02651330710755294

Phau, I., Suntornnond, V. (2006). Dimensions of consumer knowledge and its impacts on country of origin effects among Australian consumers: a case of fastconsuming product", Journal of Consumer Marketing, Vol. 23, Iss 1, 34 - 42, https://doi.org/10.1108/07363760610641145

Raharjo, L. (2012). Country Image Perception on Tertiary Education: A Pilot Study, Contemporary Management Research, Vol.8, No1, 85-92

Rakita B. (2012). Međunarodni marketing, od lokalne do globalne perspective [International marketing, from local to global perspective] Ekonomski fakultet BeogradRezvani, S., Dehkordi, G. J., Rahman, M.S., Fouladivanda, F., Habibi, M., Eghtebas, S. (2012). A Conceptual Study on the Country of Origin Effect on Consumer Purchase Intention, Asian Social Science; Vol. 8, No. 12, 205-215, DOI: http://dx.doi.org/10.5539/ass.v8n12p205

Robinson, J., Shaver, P.,\& Wrightsman, L. (1991). Criteria for Scale Selection and Evaluation, Measures of Personalily and Social Psychological Attitudes,

Roth M.S., Romeo G.B. (1992). "Matching product category and Country Image Perceptions: A framework for managing Country of Origin Effects", Journal of International Business Studies, Winter, Vol 23, No.. 3, 477-497

Sapic, S., Jovanovic M., \& Furtula, S. (2014). Entry marketing strategies of foreign companies: A case study on western Serbia, Actual Problems of Economics, Vol 156, Iss 6, 51-61

Saydan, R. (2013). Relationship between Country of Origin Image and Brand Equity: An Empirical Evidence in England Market, International Journal of Business and Social Science, Vol. 4 No. 3

Thomson, C.J., Pollio, H.R., \& Locander, W.B. (1994). The Spoken and Unspoken, Journal of Consumer Research, 21(3), 432-452.

Yang, Z., Wang, X. (2008). Does country of origin matter in the relationship between brand personality and purchase intention in emerging economies? International marketing review, Vol. 25, No4., 458-474, https://doi.org/10.1108/ 02651330810887495

Zakaria, I., Rahman, B., Othman, A, K, Mohamed Yunus, N.A., Dzulkipli, R. M., \& Faiz Osman M.A. (2014). The Relationship between Loyalty Program, Customer Satisfaction and Customer Loyalty in Retail Industry: A Case Study, Procedia - Social and Behavioral Sciences 129, 23 - 30, DOI: 10.1016/j.sbspro. 2014.03.643

Zeb, H., Rashid, K., \& Javeed, B., M. (2011). Influence of brands on female consumer's buying behavior in Pakistan, International Journal of Trade, Economics and Finance, Vol 2., No1., 225-231 


\title{
ЕФЕКАТ ЗЕМЉЕ ПОРЕКЛА ПРОИЗВОДА НА ПРОЦЕС ОСТВАРЕЊА ЛОЈАЛНОСТИ ПОТРОШАЧА
}

\author{
Срђан Шапић, Милан Коцић, Катарина Радаковић \\ Универзитет у Крагујевцу, Економски факултет, Крагујевац, Србија
}

\section{Резиме}

Процес понашања потрошача, као изузетно комплексан маркетиншки појам, налази се под утицајем бројних варијабли које се свакодневно истражују у маркетиншкој теорији и пракси. Разматрање понашања потрошача утолико је сложеније када се предузећа поред наступа на домаћем тржишту одлуче да своје пословање прошире изван националних граница. Тада лојалност потрошача може бити под утицајем бројних фактора. Један од њих јесте и земља порекла производа. Неретко се дешава да потрошачи карактеристике одређених производа везују управо за земљу из које исти потичу. Због тога је за ауторе било посебно интересантно испитати на који начин земља порекла производа утиче на лојалност потрошача посредством квалитета, дизајна и престижа који је повезан са коришћењем производа из одређених земаља. У складу са постојећим прегледом литературе из дате области, за ауторе су посебно занимљиви закључци који могу имати значајне импликације за привредне субјекте на територији Србије. Применом регресионе анализе утврђено је да све три варијабле, дакле, квалитет производа, дизајн и престиж, утичу на лојалност потрошача када је у питању земља порекла производа. Највећи утицај на стварање лојалности потрошача када се разматра утицај земље порекла има престиж који потрошачи осећају у вези са коришћењем ових производа. Анализирање датог проблемског подручја обухватило је једнофакторску анализу варијансе како би се испитале разлике између различитих категорија испитаника које су биле обухваћене истраживањем. Тако је уочено да не постоје статистички значајне разлике са аспекта пола испитаника када се испитује ефекат земље порекла производа. Нешто другачији резултати забележени су када се посматра старосна структура испитаника. Ипак, без обира на уочене разлике, од суштинског значаја за ствараоце маркетиншких стратегија и позиционирање на конкурентном тржишту јесте чињеница да је земља порекла производа један од веома значајних критеријума који утичу на понашање потрошача и доприносе стварању њихове лојалности. 